\title{
Technical and Environmental Impacts of Coal Waste Used as a Soil Stabilizer in Construction Projects of Forest Roads
}

\author{
Sara Mansouri, Mehran Nasiri, Amir Modarres
}

\begin{abstract}
Many pozzolans are waste products from industrial processes. Every year a huge amount of coal waste is gathered from the coal washing plant in the Hyrcanian forests of Iran. These materials can be used for soil stabilization in construction and maintenance projects of forest roads. This paper aims to (a) investigate the role of coal waste (CW) as a soil stabilizer and (b) determine the changes in soil specification regarding the environmental pollution in different combinations of materials (soil, lime (4 and $6 \%$ ) and $C W(3,6,9$ and $12 \%)$ ). For this purpose, different technical and environmental analysis and laboratory tests were performed. Technical tests showed that the soil liquid limit and maximum dry density decreased with an increase in lime and $C W$ contents. Addition of $C W$ could increase the soil CBR, UCS and OMC. According to XRD test, the addition of $C W$ and lime can increase the size of crystals in stabilized soil samples. Environmental analysis showed that the use of stabilizer significantly reduced the concentration of heavy metals such as $\mathrm{Cd}, \mathrm{Cr}$ and $\mathrm{Pb}$. Also, all of the metal concentrations leached from samples satisfied the required criteria, but the addition of lime and CW increased the concentration of $N, P$, and $K$. These changes can increase the invasive species consistent with calcareous soil conditions along the roads. According to the results, the combination of coal waste and lime can be one of the best methods for in situ remediation. It would, however, be better to use a minimum amount of stabilizer in pavement layers of access roads due to environmental sensitivity.
\end{abstract}

Keywords: stabilization, forest, dump, road construction, remediation, landfill

\section{Introduction}

The materials including loose sands, soft clays and organic matter are not adequate materials in construction and repair projects of access roads. Stabilization of materials is one of the usual methods used to improve the quality of access roads materials and reduce the total thickness of pavement layer, leading to a reduction in forestry project costs (Modarres and Nosoudy 2015, Nasiri et al. 2016, Hruza et al. 2020). Low cost and availability as well as the stabilization capability of coal waste $(\mathrm{CW})$ have led many researchers to investigate $\mathrm{CW}$ as an alternative for soil stabilization (Seco et al. 2011, Garcia et al. 2012, Fauzi et al. 2013, Li et al. 2015, Modarres and Nosoudy 2015, Taslimi Paein Afrakoti et al. 2020). Waste management issue in forest area is one of the biggest challenge in the Hyrcanisn forest of
Iran, as the waste depot produced from industries causes major environmental damage (Lee et al. 2011, Ahmed 2015, Li et al. 2015). Some industries (such as Alborz Markazi) operate in the forests area, so these industries produce a large amount of coal waste during a day (about 250 tons.) Due to the lack of conversion industries, many of these waste materials may be dumped on natural forest without use for years. Unfortunately, in recent years, no regulations have been issued for the disposal of coal wastes. In Iran, coal waste has been used for various purposes such as the production of cement and concrete (Modarres and Nosoudy 2015, Taslimi Paein Afrakoti et al. 2020). It was also used for the road construction project at the research level. However, coal waste has not been used in construction and maintenance projects of forest roads. Utilizing the waste materials keeps these materials 
from being dumped into landfills near forest area and these materials offer a cheaper method for stabilizing soils. The addition of coal ash to stabilized soil containing conventional stabilizers such as lime increased the material strength and improved its durability against moisture and freeze-thaw conditioning (Obozor et al. 2012, Lu et al. 2014, Ahmed 2015, Modarres and Nosoudy 2015, Taslimi Paein Afrakoti et al. 2020). Modarres et al. (2015) stated that the combination of coal wastes and lime, significantly increases the compressive strength and CBR rates. Kamei et al. (2013) stated that, due to the addition of the recycled coal ash and basanite, the strength and durability of very soft clayey soil significantly increased. Taslimi Paein Afrakoti et al. (2020) investigated the effect of the coal wastes on the mechanical properties of sandy soil. This study reported that the addition of the optimum amount of CW (5\%) improves the mechanical properties of samples containing $6 \%$ cement, while the replacement of cement with CW constantly reduces mechanical properties in samples containing 3\% cement.

Coal is mostly carbon with different amounts of elements such as hydrogen, sulfur, oxygen, and nitrogen that is expected to cover approximately $50 \%$ of the global energy consumption by 2030 (Li et al. 2015). Coal waste contains toxic heavy metals and causes harmful impacts on the natural environment, such as the leakage of heavy metals into the underground resources (USEPA 1311, 1992). This leakage significantly reduces the water quality and has a profound effect on the vegetation growth in the mining area. Almost 5.5 billion tons of coal is produced worldwide and about half of these coal is buried as waste material every year (Garcia et al. 2012, Modarres and Nosoudy 2015). The stabilized layers are usually in direct contact with the surface or underground water resources. Several recent research studies have indicated that stabilization method was a promising technique for in situ remediation of some pollutant materials (Mench et al. 2000, Kumpiene et al. 2007, Modarres and Nosoudy 2015). Coal and biofuel combustion and fly ashes are alkaline materials with high absorptive capacity (Ahmed 2015). Industrial by-products such as fly ashes, red mud, biosolids, dolomitic residues and berringite have been shown to contribute to metal immobilization. Kumpiene et al. 2007 stated that, after the soil stabilizing process, the rate of copper and lead leakage reduced as much as 98 and $100 \%$, respectively.

Minimum standards are considered for pavement materials of forest roads due to the traffic volume and economic situation of forestry projects of Iran. According to the environmental pollution of waste materials such as coal wastes in forest area, consideration of coal wastes as pozzolanic materials and its availability, these materials can be used for soil stabilization. Therefore, this paper aims to:

$\Rightarrow$ investigate the role of coal waste (CW) as a soil stabilizer of subgrade materials

$\Rightarrow$ determine the changes in soil specification regarding the environmental pollution in different combinations of soil, lime and CW.

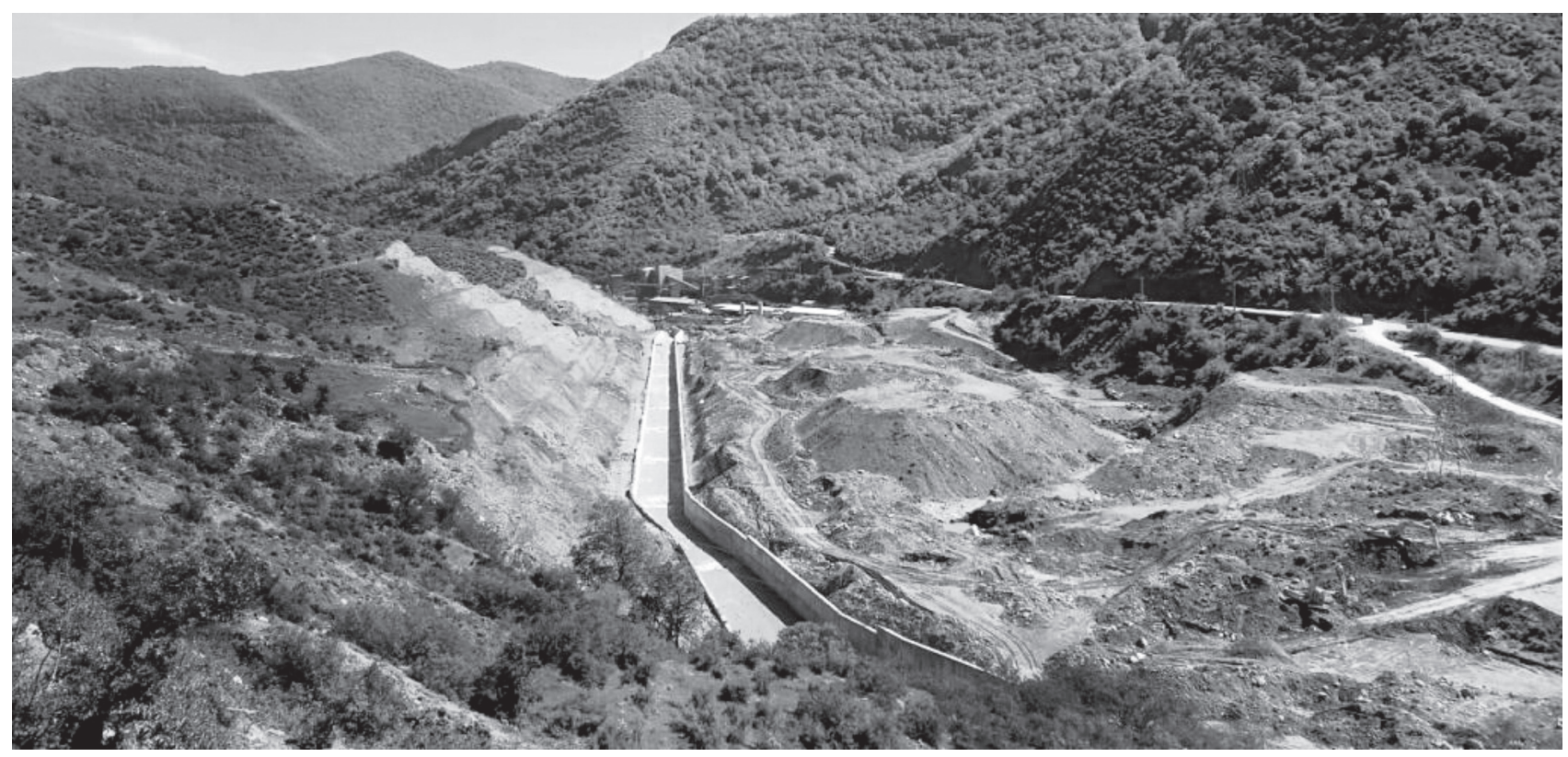

Fig. 1 Alborz Markazi coal washing plant in forest area 
Technical and Environmental Impacts of Coal Waste Used as a Soil Stabilizer in Construction ... (491-500) S. Mansouri et al.

\section{Materials and Methods}

\subsection{Study Area}

This study was carried out in the Alborz Markazi coal washing plant (Fig. 1), in northern Iran, approximately on the coordinates $36^{\circ} 19^{\prime \prime} 72^{\prime \prime} \mathrm{N}$ and $52^{\circ} 83^{\prime} 22^{\prime \prime} \mathrm{E}$. The climate of the studied area is affected by the Caspian Sea and its relative humidity is high throughout the year with an average of 80 percent. The average precipitation in the area is $800 \mathrm{~mm}$. There is a deciduous forest in this area and the main woody species in Kaselian forest are oriental beech (Fagus orientalis Lipsky), European hornbeam (Carpinus betulus L.), Persian ironwood (Parrotia persica C.A.Mey) and black alder (Alnus glutinosa L.). In this region, more than 250 tons of coal waste are gathered from the Alborz Markazi coal washing plant during a day. There are rivers close to this plant, namely Dalilam, Sheshrudbar, Apen and Kelarijan. In this region, the road network is used by forestry machinery and public transport on holidays as there are tourist areas in natural forests. This traffic can increase the sediment delivery from unpaved roads. One of the most important solutions to reduce sediment delivery from forest roads as well as strengthen the road materials is the use of soil stabilizers.

\subsection{Materials}

About $400 \mathrm{~kg}$ of soil were collected from the borrow area in the Kaselian forests. Soils were put in bags and transferred to the soil-bioengineering laboratory of SANRU (University of Sari Agricultural Sciences and Natural Resources). Soil mechanics tests such as sieve analysis and specific gravity (Gs) and Aterrbeg limits were done. The specific gravity (Gs) of soil samples were determined using a pycnometer (ASTMD854). The dried soil samples were placed in the topmost sieve and dry sieving was carried out using a mechanical sieve shaker for a minimum period of $10 \mathrm{~min}$. Also, the liquid and plastic limits of the soil were determined in order to study the Aterrberg limits and classify the soil. More information about engineering properties of the studied soil is presented in Table 1.
Table 1 Properties of the studied soil

\begin{tabular}{|l|c|}
\hline \multicolumn{1}{|c|}{ Laboratory tests } & Rate \\
\hline Liquid limit, \% & 41.2 \\
\hline Plastic limit, \% & 30.8 \\
\hline Plasticity index, \% & 10.4 \\
\hline specific gravity, Gs & 2.71 \\
\hline OMC, \% & 19.2 \\
\hline MDD, Mg m ${ }^{-3}$ & 1.57 \\
\hline CBR owc, \% & 13.1 \\
\hline AASHTO classification & A-5(3) \\
\hline pH & 6.28 \\
\hline EC, ds m ${ }^{-1}$ & 0.46 \\
\hline N, \% & 0.15 \\
\hline P, \% & 9.5 \\
\hline K, \% & 356.7 \\
\hline C, \% & 0.91 \\
\hline
\end{tabular}

*OMC: optimum moisture content; MDD: Maximum dry density; CBR: California bearing ratio; AASHTO: American Association of State Highway and Transportation Officials; $\mathrm{N}$ - nitrogen; $\mathrm{p}$ - phosphorus; $\mathrm{K}$ - potassium; $\mathrm{C}$ - carbon

\subsection{Coal Waste (CW) and Hydrated Lime}

In this research, coal waste was collected from the existing dumps in Alborz Markazi coal washing plant. The hydrated lime (HL) was applied for stabilization. Table 2 shows the chemical composition of coal waste and hydrated lime. According to Table 2, CW consisted of significant pozzolanic compounds $\left(\mathrm{SiO}_{2}\right)$. A combination of HL with coal waste could compensate the low free lime available and activate the pozzolanic compounds in these materials.

\subsection{Mix Design}

Table 3 shows the mix design of materials. Some studies have considered a value of $5 \%$ for coal waste consumption by dry weight of soil (Taslimi Paein Afrakoti et al. (2020)); some other proposed the value of

Table 2 Chemical composition of coal waste and hydrated lime (\% by total weight)

\begin{tabular}{|l|c|c|c|c|c|c|c|c|c|}
\hline & $\mathrm{Fe}_{2} \mathrm{O}_{3}$ & $\mathrm{SiO}_{2}$ & $\mathrm{MgO}$ & $\mathrm{K}_{2} \mathrm{O}$ & $\mathrm{Na}_{2} \mathrm{O}$ & $\mathrm{Al}_{2} \mathrm{O}_{3}$ & $\mathrm{TiO}_{2}$ & $\mathrm{CaO}$ & $\mathrm{LOI}^{*}$ \\
\hline $\mathrm{CW}$ & 4.7 & 35.6 & 0.79 & 3.3 & 0.26 & 15.6 & 1.1 & 1.45 & 37.2 \\
\hline $\mathrm{HL}$ & 0.1 & 1.1 & 0.57 & $<0.1$ & 0.23 & 0.68 & $<0.1$ & 73.1 & 24.1 \\
\hline
\end{tabular}

* Ioss on ignition 
Table 3 Investigated mixtures and mentioned indices

\begin{tabular}{|l|c|}
\hline \multicolumn{1}{|c|}{ Mix design } & Index \\
\hline \multicolumn{1}{|c|}{ Natural soil } & $\mathrm{S}$ \\
\hline Soil $+4 \%$ Lime $+3 \% \mathrm{CW}^{*}$ & $\mathrm{~S}+4 \mathrm{~L}+3 \mathrm{CW}$ \\
\hline Soil $+4 \%$ Lime $+6 \%$ CW & $\mathrm{S}+4 \mathrm{~L}+6 \mathrm{CW}$ \\
\hline Soil $+4 \%$ Lime $+9 \%$ CW & $\mathrm{S}+4 \mathrm{~L}+9 \mathrm{CW}$ \\
\hline Soil $+4 \%$ Lime $+12 \%$ CW & $\mathrm{S}+4 \mathrm{~L}+12 \mathrm{CW}$ \\
\hline Soil $+6 \%$ Lime $+3 \%$ CW & $\mathrm{S}+6 \mathrm{~L}+3 \mathrm{CW}$ \\
\hline Soil $+6 \%$ Lime $+6 \%$ CW & $\mathrm{S}+6 \mathrm{~L}+6 \mathrm{CW}$ \\
\hline Soil $+6 \%$ Lime $+9 \% \mathrm{CW}$ & $\mathrm{S}+6 \mathrm{~L}+9 \mathrm{CW}$ \\
\hline Soil $+6 \%$ Lime $+12 \% \mathrm{CW}$ & $\mathrm{S}+6 \mathrm{~L}+12 \mathrm{CW}$ \\
\hline
\end{tabular}

${ }^{*}$ Coal waste

$3,6,9$ and $12 \%$ by dry weight (Modarres and Nosoudy 2015). In this study, the CW values of $3,6,9$ and $12 \%$ were considered in order to compare different combinations of material in terms of heavy metals concentration. Also, a minimum use of lime ( $4 \%$ and $6 \%$ ) was considered due to the environmental and marginal effects of lime in natural forests.

\subsection{Testing Program}

\subsubsection{Soil Mechanic Test}

Materials were prepared according to the mix design and studied using tests of CBR (California Bearing Ratio), UCS (unconfined compressive strength), Aterberg and Compaction. The CBR-test is a common test for assessing the strength of stabilized soils, and it is used to estimate the bearing strength of road subbase and subgrade. Also, the Proctor compaction tests were performed in accordance with the standard ASTM D698(2002) in CBR mould; this test shows how much free space of aggregates is filled by stabilizers and how they affect the optimum water content. The unconfined compressive strength (UCS) test is one of the methods to evaluate the strength of stabilized soil. In this study, the test was performed in accordance with the standard ASTM D 2166 for samples with 28-day curing time. The samples were compacted at optimum moisture content and kept in a mold for $24 \mathrm{~h}$. Curing continued at $25^{\circ} \mathrm{C}$ after removing the samples from the mold and the test was accomplished on specimens after 28 days of curing. During the curing process, the samples were covered by plastic envelope to prevent rapid moisture removal. The Aterberg limits test was performed based on the ASTM D4318-05. This test can show how much addi- tive could improve soil properties in terms of Aterberg limits. The $\mathrm{pH}$ was measured in accordance with the standard ASTM D4972 in distilled water and $0.1 \mathrm{M}$ of calcium chloride solution. This test can show how the acidity of the soil changes after the addition of lime and coal waste to the treatments.

\subsection{Soil Chemical Test}

\subsubsection{X-Ray Diffraction (XRD)}

To facilitate the macro-behavior comparison and explanation, the X-ray diffraction (XRD) tests were performed using the PHILIPS (PW1730) instrument to qualitatively identify the micro-structural developments of the stabilized samples $(\mathrm{S}+4 \mathrm{~L}+9 \mathrm{CW}$ and $\mathrm{S}+6 \mathrm{~L}+12 \mathrm{CW})$. Also, $\mathrm{X}$-ray test was performed for the control sample to compare XRD patterns between the natural soil and stabilized samples. After complete drying, the specimens were pulverized and sieved. The powder finer than $50 \mu \mathrm{m}$ was collected and mixed with methanol. The specimen was oven dried for about $20 \mathrm{~min}$ prior to testing. This test was performed with two replications for natural soil and four replications for combinations of $\mathrm{S}+4 \mathrm{~L}+9 \mathrm{CW}$ and $\mathrm{S}+6 \mathrm{~L}+12 \mathrm{CW}$.

\subsubsection{Toxicity Characteristic Leaching Procedure (TCLP)}

The water penetrated the road pavement and subgrade layers could directly seep to underground water resources. So, there would be a high risk of water pollution through leaching the hazardous materials such as heavy metals into underground water resources. TCLP is one of the leaching procedure tests used to analyze the risk of heavy metal from the stabilized soils. About $10 \mathrm{~g}$ of the samples was placed in a container made of polypropylene. To do so, about $200 \mathrm{ml}$ of deionized water and acetic acid was added to the beaker containing the sample. Then, samples vibrated at a rate of $30 \mathrm{rpm}$ for $18 \mathrm{~h}$ at $20^{\circ} \mathrm{C}$. Samples were placed on a glass fiber, and acetic acid solution was added to the obtained leachate until the $\mathrm{pH}$ of the solution became less than 2 . The obtained leachate was assessed with inductively coupled plasma atomic emission spectrometer machine and the concentrations of heavy metals were determined. This test was performed with three replications for combinations of $\mathrm{S}+4 \mathrm{~L}+3 \mathrm{CW}, \mathrm{S}+4 \mathrm{~L}+9 \mathrm{CW}, \mathrm{S}+6 \mathrm{~L}+3 \mathrm{CW}$ and $\mathrm{S}+6 \mathrm{~L}+9 \mathrm{CW}$.

\subsection{Data Analysis}

All computations were done using SPSS (Statistical Package for the Social Sciences) version 16. This included assumptions of normality test and one-way analysis of variance (ANOVA) to compare means among treatments. The graphical displays were made using the Excel software. 


\section{Results}

\subsection{Aterberg Limit}

According to the results, the soil liquid limit decreased with an increase in lime and CW contents (Fig. 2). In this study, the liquid limit of natural soil of $41.2 \%$ was recorded. According to Fig. 2, it can be found that $6 \% \mathrm{CW}$ can reduce the soil liquid limit to $31.8 \%$. The plasticity index of natural soil of $10.4 \%$ was recorded. In most experimental treatments, the plasticity index decreased with an increase in the CW. The addition of $6 \% \mathrm{CW}$ was able to reduce the plasticity index to $5 \%$.

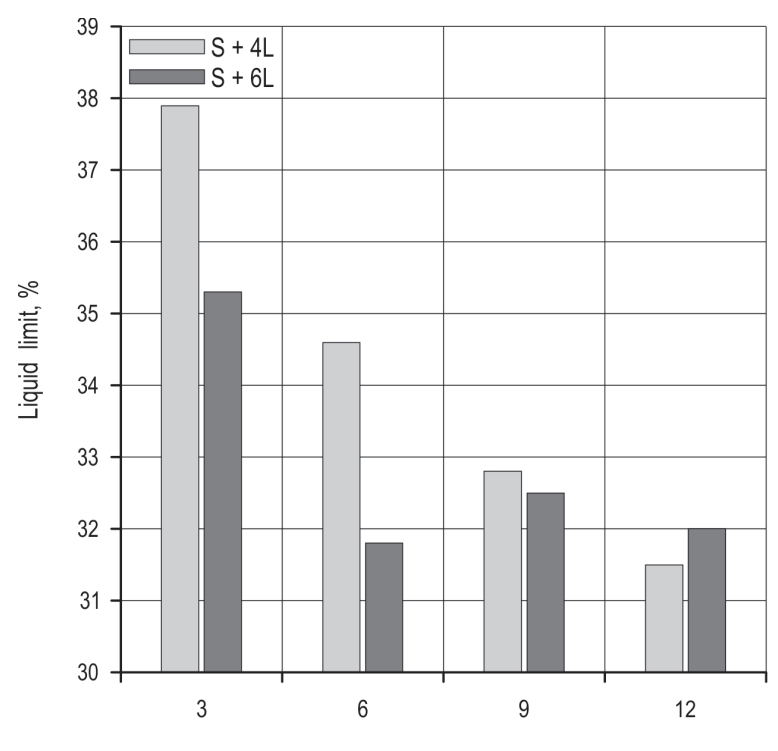

$\mathrm{CW}, \%$

Fig. 2 Influence of CW and lime on liquid limit and plasticity index

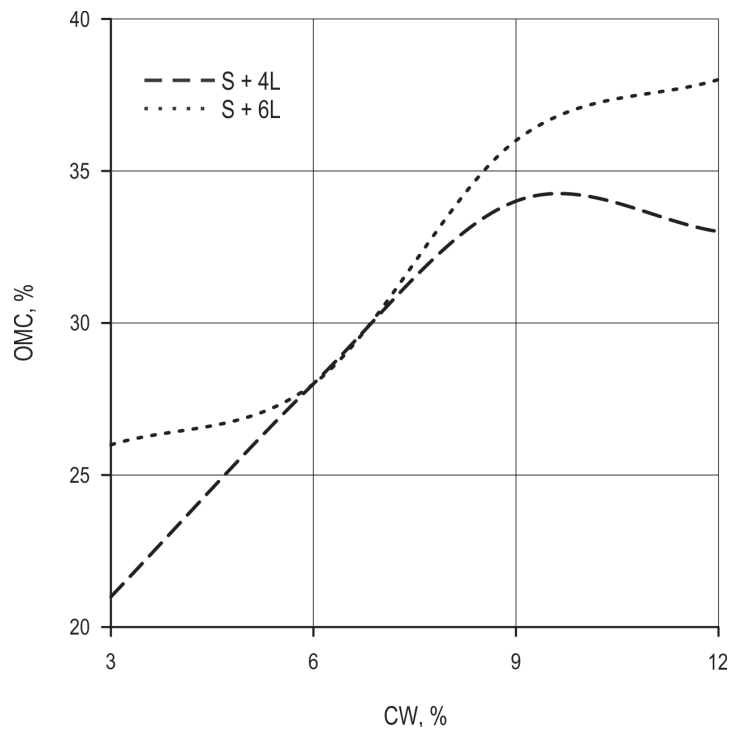

Fig. 3 Influence of CW and lime on OMC parameter

\subsection{Compaction Properties}

According to Fig. 3, the OMC of stabilized soil increased with an increase in lime and CW contents. The rate of OMC for natural soil and S+6\% Lime of 19.2 and $26.4 \%$ was recorded, respectively. The soil OMC for the combinations of $\mathrm{S}+4 \mathrm{~L}+9 \mathrm{CW}$ and $\mathrm{S}+6 \mathrm{~L}+9 \mathrm{CW}$ increased by $14.9 \%$ and $16.8 \%$, respectively, compared to the natural soil.

Based on Fig. 4, adding CW and lime to the soil reduced the maximum dry density. Given that the MDD for natural soil and S+6\% Lime was $1.57 \mathrm{Mg} \mathrm{m}^{-3}$
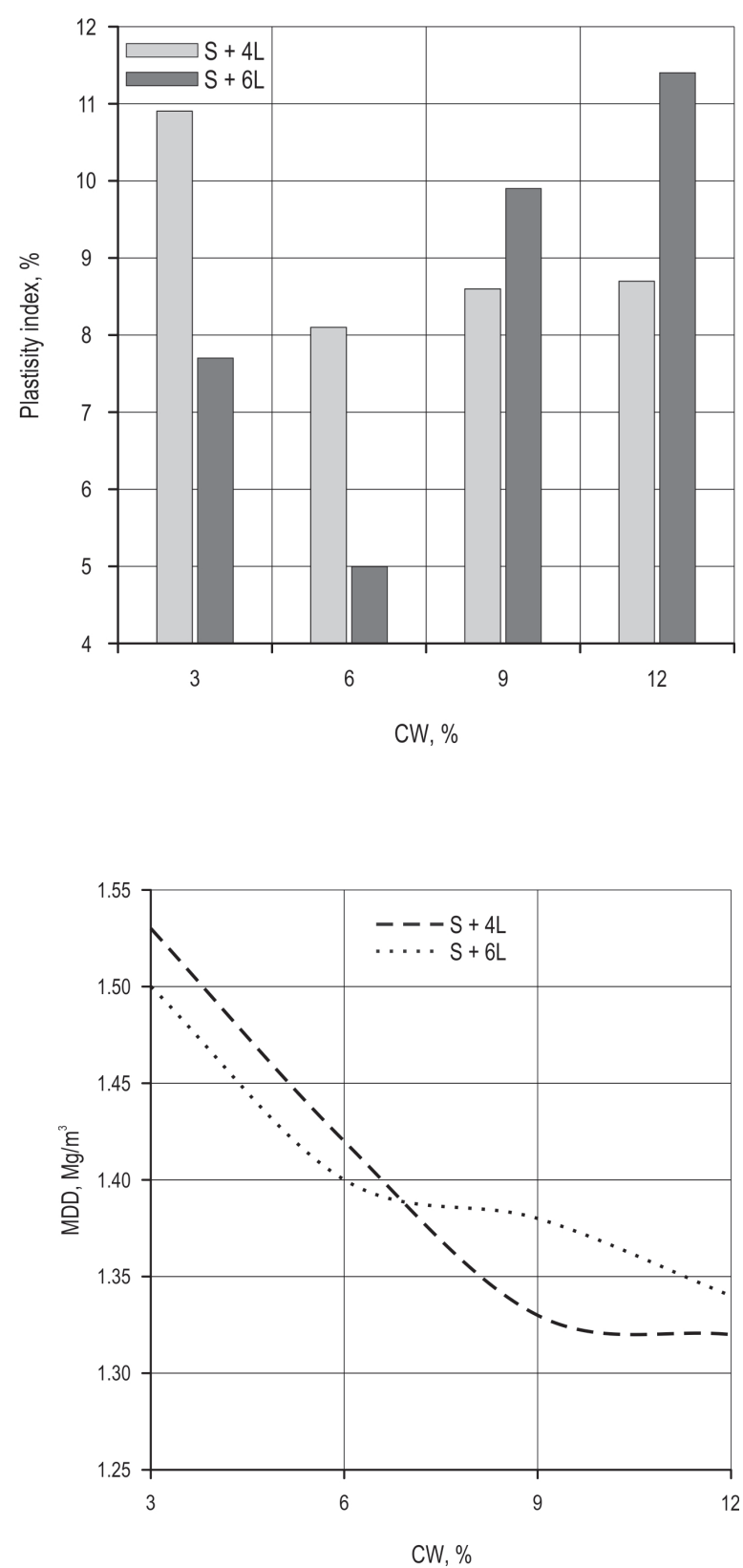

Fig. 4 Influence of CW and lime on MDD parameter 
and $1.46 \mathrm{Mg} \mathrm{m}^{-3}$, respectively, adding $9 \% \mathrm{CW}$ was able to reduce the MDD to $1.33 \mathrm{Mg} \mathrm{m}^{-3}$.

\subsection{Strength Properties}

According to Fig. 5, the addition of CW could increase the soil CBR, but the increasing trend varied for different percentages. For example, the treatment of $\mathrm{S}+6 \mathrm{~L}+9 \mathrm{CW}$ reached the highest effectiveness on CBR and then dropped. The maximum differences recorded for CBR were $37.5 \%$ and $28 \%$ higher than for natural soil and S+6L. Also the addition of CW improves the soil strength properties. The maximum UCS $(842 \mathrm{kPa})$ was recorded at low strain rate (about $0.4 \%$ ) for natural

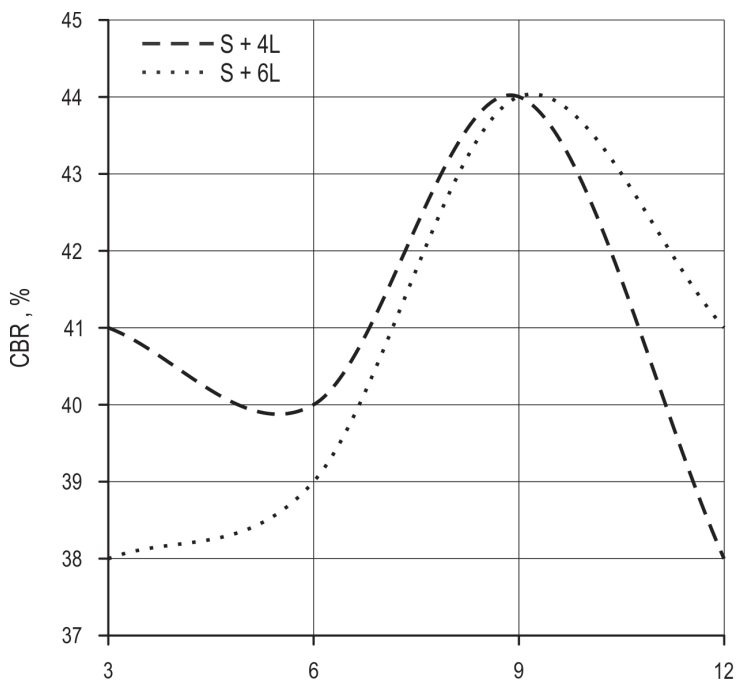

$\mathrm{CW}, \%$

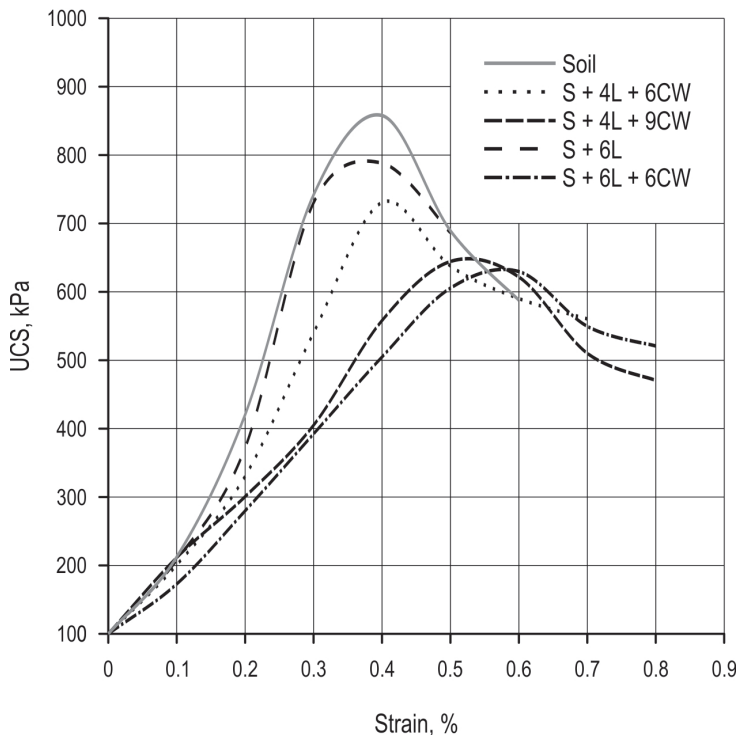

Fig. 5 Influence of CW and lime on CBR parameters and UCS (28 day curing time)
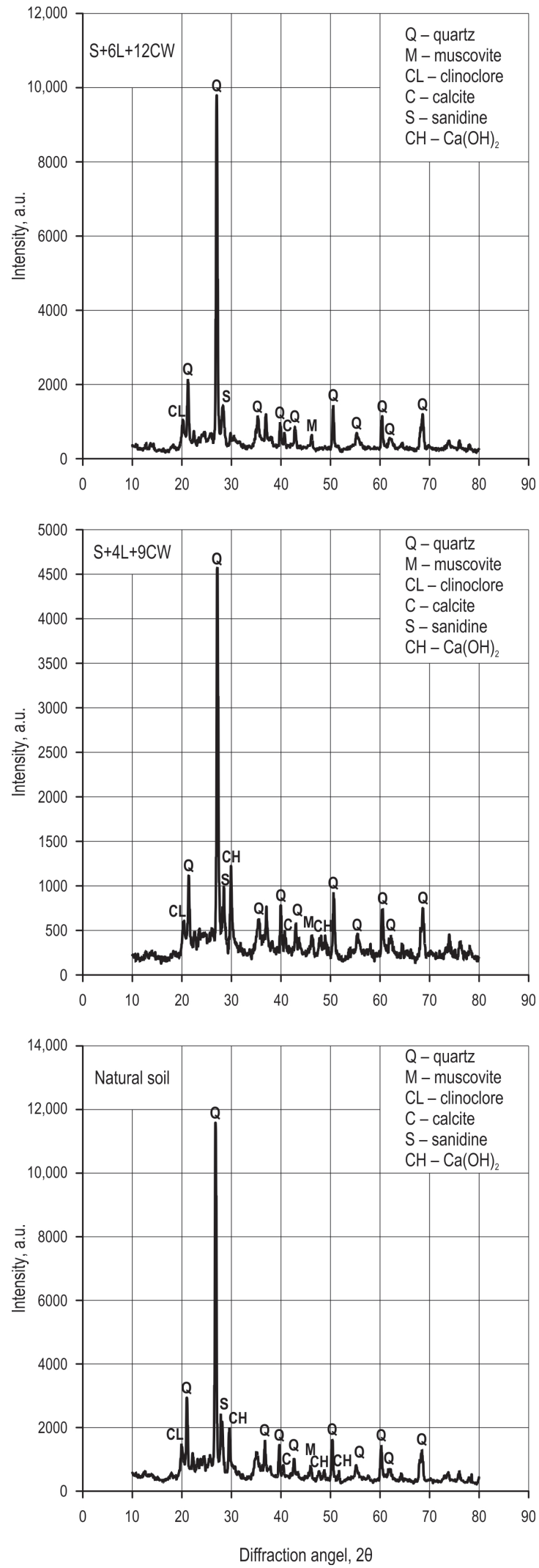

Fig. 6 Results of XRD test for different combinations of materials 
soil (Fig. 5). The rate of UCS (765 kPa) showed no great changes with increasing in lime (6\% lime). However, the addition of $\mathrm{CW}$ to the soil could increase the strength of materials, so that the strain rate of stabilized material of $0.6 \%$ was measured, which was higher than that of the natural soil.

\subsection{X-Ray Diffraction (XRD)}

Fig. 6 showes the XRD patterns obtained for different combinations of materials. The most important mineral in the studied soil are kaolinite, montmorillonite, quartz, calcite and sanidine. Clay minerals, such as montmorillonite and kaolinite, were detected in all samples but with the weaker appearance in stabilized samples containing lime and CW. Changes in the quartz intensity, especially at 28 degrees, can be seen in Fig. 6 . A change is also observed at the peak of the graph, which is related to the addition of lime and coal waste. The peak intensity decreased from 13,350 counts for the natural soil to 9310 counts for stabilized samples $(\mathrm{S}+4 \mathrm{~L}+9 \mathrm{CW})$.

\subsection{Chemical Tests}

\subsubsection{Concentration of Heavy Metals}

According to Table 4, the concentrations of $\mathrm{Cr}$ and $\mathrm{Pb}$ in the $\mathrm{CW}$ were higher than the regulatory levels (the recommendations of the Environmental Protection Agency of America). The addition of coal waste

Table 4 TCLP analysis for different combinations of materials

\begin{tabular}{|c|c|c|c|c|c|c|c|c|}
\hline \multicolumn{2}{|c|}{ Parameter } & CW & $S+4 L+3 C W$ & $S+4 L+9 C W$ & $S+6 L+3 C W$ & $S+6 L+9 C W$ & ANOVA, $p$ & Regulatory level ${ }^{*}$ \\
\hline \multirow{2}{*}{$\mathrm{Cd}, \mathrm{mg} / \mathrm{l}$} & $\mathrm{M}^{*}$ & $0.44^{c}$ & $0.22^{b}$ & $0.14^{\mathrm{ab}}$ & $0.21^{b}$ & $0.1^{\mathrm{a}}$ & 0.000 & 1 \\
\hline & $\mathrm{SD}^{*}$ & 0.02 & 0.03 & 0.05 & 0.03 & 0.02 & & \\
\hline \multirow{2}{*}{$\mathrm{Cr}, \mathrm{mg} / \mathrm{l}$} & $\mathrm{M}$ & $5.65^{b}$ & $1.15^{\mathrm{a}}$ & $1.27^{\mathrm{a}}$ & $0.2^{\mathrm{a}}$ & $0.17^{\mathrm{a}}$ & 0.000 & 5 \\
\hline & SD & 1 & 0.39 & 0.21 & 0.03 & 0.06 & & \\
\hline \multirow{2}{*}{$\mathrm{Pb}, \mathrm{mg} / \mathrm{l}$} & $M$ & $11.4^{\mathrm{a}}$ & $5.37^{\mathrm{b}}$ & $2.53^{\mathrm{bc}}$ & $3.27^{\mathrm{bc}}$ & $1.86^{\mathrm{C}}$ & 0.000 & 5 \\
\hline & SD & 2 & 0.68 & 0.93 & 1.04 & 0.4 & & \\
\hline \multirow{2}{*}{$\mathrm{Ni}, \mathrm{mg} / \mathrm{l}$} & $M$ & $6.4^{b}$ & $2.8^{\mathrm{a}}$ & $2.1^{a}$ & $2.93^{\mathrm{a}}$ & $1.27^{\mathrm{a}}$ & 0.000 & 25 \\
\hline & SD & 0.65 & 0.7 & 0.7 & 0.72 & 0.47 & & \\
\hline \multirow{2}{*}{ As, mg/l } & $M$ & $2.98^{b}$ & $3.4^{b}$ & $2.13^{b}$ & $2.66^{b}$ & $0.16^{\mathrm{a}}$ & 0.000 & 0.2 \\
\hline & SD & 0.53 & 0.98 & 0.25 & 0.65 & 0.04 & & \\
\hline \multirow{2}{*}{ Cu, mg/l } & $\mathrm{M}$ & $0.72^{b}$ & $0.46^{\mathrm{ab}}$ & $0.30^{\mathrm{a}}$ & $0.64^{b}$ & $0.28^{\mathrm{a}}$ & 0.004 & 25 \\
\hline & SD & 0.17 & 0.15 & 0.09 & 0.1 & 0.03 & & \\
\hline
\end{tabular}

* The recommendations of the Environmental Protection Agency of America (EPA), (USEPA, 1311, 1992); a* Within-a-row means followed by the same letter are not significantly different; M: mean; SD: standard deviation

Table 5 Chemical characteristics of different combinations of materials

\begin{tabular}{|c|c|c|c|c|c|c|c|c|}
\hline \multicolumn{2}{|c|}{ Parameter } & \multirow{2}{*}{$\begin{array}{l}\text { Soil } \\
0.15^{b}\end{array}$} & \multirow{2}{*}{$\frac{C W}{0.25^{a b}}$} & \multirow{2}{*}{$\frac{S+4 L+3 C W}{0.36^{\mathrm{ab}}}$} & \multirow{2}{*}{$\frac{S+4 L+9 C W}{0.44^{\mathrm{a}}}$} & \multirow{2}{*}{$\frac{S+6 \mathrm{~L}+3 \mathrm{CW}}{0.4^{\mathrm{a}^{*}}}$} & \multirow{2}{*}{$\frac{S+6 L+9 C W}{0.42^{a}}$} & \multirow{2}{*}{$\begin{array}{c}\text { ANOVA, } p \\
\mathbf{0 . 0 1}\end{array}$} \\
\hline $\mathrm{No}$ & $\mathrm{M}^{*}$ & & & & & & & \\
\hline $\mathrm{N}, \%$ & $S D^{*}$ & 0.02 & 0.09 & 0.07 & 0.1 & 0.68 & 0.13 & \\
\hline \multirow{2}{*}{$\mathrm{P}, \%$} & $M$ & $9.5^{d}$ & $106.5^{c}$ & $137.5^{\mathrm{ab}}$ & $147.3^{a b}$ & $156.1^{\mathrm{a}}$ & $125.7^{\text {bc }}$ & 0.000 \\
\hline & SD & 0.5 & 7.24 & 14.25 & 3.4 & 11.54 & 8.1 & \\
\hline \multirow{2}{*}{$K, \%$} & $\mathrm{M}$ & $356^{c}$ & $1623^{b}$ & $2321^{a}$ & $2155^{a}$ & $2235^{a}$ & $2340^{a}$ & 0.000 \\
\hline & SD & 61 & 245 & 162 & 232 & 119 & 253 & \\
\hline \multirow{2}{*}{$C, \%$} & $M$ & $0.91^{b}$ & $1.08^{b}$ & $1.96^{\mathrm{a}}$ & $2.03^{a}$ & $2.03^{a}$ & $2.03^{a}$ & 0.000 \\
\hline & SD & 0.08 & 0.12 & 0.4 & 0.2 & 0.5 & 0.3 & \\
\hline \multirow{2}{*}{$\mathrm{pH}$} & $M$ & $6.28^{d}$ & $7.17^{c}$ & $7.23^{b}$ & $7.13^{c}$ & $8.13^{a}$ & $8.11^{a}$ & 0.000 \\
\hline & SD & 0.01 & 0.02 & 0.015 & 0.011 & 0.02 & 0.015 & \\
\hline \multirow{2}{*}{$\mathrm{EC}$} & $\mathrm{M}$ & $0.46^{d}$ & $0.61^{\text {cd }}$ & $0.73^{\mathrm{bc}}$ & $0.73^{\mathrm{bc}}$ & $0.84^{\mathrm{ab}}$ & $0.99^{a}$ & 0.000 \\
\hline & SD & 0.03 & 0.05 & 0.04 & 0.06 & 0.04 & 0.09 & \\
\hline
\end{tabular}

$a^{*}$ Within-a-row means followed by the same letter are not significantly different; M: mean; SD: standard deviation 
and lime to the soil significantly reduced the concentration of heavy metals such as $\mathrm{Cd}, \mathrm{Cr}$ and $\mathrm{Pb}(p<0.05)$. In coal waste, the concentration rate of $\mathrm{As}$ and $\mathrm{Cu}$ was recorded as 2.98 and $0.72 \mathrm{mg} / \mathrm{l}$. In most cases, a significant difference was observed between the coal waste and materials stabilized with lime and CW in terms of heavy metals concentration. According to the laboratory results, the concentration of chromium and lead was significantly decreased, while their concentration was decreased by 5.48 and $9.54 \mathrm{mg} / \mathrm{l}$ in the combination of $S+6 L+9 \mathrm{CW}$, respectively. According to Table 4, this significant reduction was also recorded for other heavy metals.

\subsubsection{Chemical Analysis}

The results of chemical analysis showed that the addition of different compounds of lime and CW to the soil significantly increased the concentration of elements such as N, P, K and C as well as $\mathrm{pH}$ and EC. According to Table 5, soil pH increased from 6.28 to 8.11.

\section{Discussion}

According to the soil mechanical tests, coal waste affects the liquid and plastic behavior of soil. The main reason for the reduction of liquid and plastic limits could be the chemical reaction between the lime and soil, because this chemical reaction requires more moisture and provides it from the soil (Modarres and Nosoudy 2015). Also, the progression rate of ion exchange reaction is the most important factor that modifies the plastic behavior of the treated soil (Khemissa and Mahamedi 2014). During this reaction, the single valence ions are replaced by divalent ions of calcium. This interplay reduces the water absorption of the soil particles (Modarres and Nosoudy 2015). According to the results, the OMC of stabilized soil increased with an increase in lime and CW contents and adding CW and lime to the soil reduced the MDD. The addition of $\mathrm{CW}$ and lime reduced the quantity of free silt and clay fraction, forming coarser materials with larger surface areas. So, more water was needed to compaction (Ramezanianpour et al. 2009). The reduction in MDD can be related to the coating of soil by $\mathrm{CW}$ and lime, which results in large particles with larger voids and less density. The formation of hard cementitious matrix due to the presence of calcium hydroxide in stabilized soil reduces the compactibility and therefore the maximum dry density of stabilized soil (Ramezanianpour et al. 2009, Chobbasti et al. 2010). According to the soil mechanical tests, the addition of CW to the soil could increase the strength of materials. The reduction of the clay minerals in stabilized material could be related to the occurrence of the pozzolanic reaction. The trend is in line with Sezer et al. 2006, Consoli et al. 2009,
Modarres and Nosoudy (2015), who indicated that more strength and higher density were produced by hydration processes than other crystals. Also, the subsequent increase in the UCS is attributed to the formation of cementitious compounds between the $\mathrm{CaOH}$ present in the soil and CW, as well as the pozzolans present in the stabilizers (Harichane et al. 2011, Taslimi Paein Afrakoti et al. 2020). According to the XRD pattern, the changes of the graph's peak can be attributed to the partial destruction of silicate mineral structure including quartz due to high $\mathrm{pH}$ in the lime treated soils. Similar results have been reported in several relevant researches (Sezer et al. 2006). Changes in quartz intensity can increase the size of crystals in soil samples, and the presence of Calcite can improve the strength of the soil (Ahmed 2015).

According to the TCLP test, the addition of coal waste and lime to the soil significantly reduced the concentration of heavy metals. Modarres and Nosoudy (2015) stated that the combination of lime and CW with clay stabilizes the soil as well as the heavy metals available in coal, keeping the leakage of pollutants into water resources within the regulatory levels. The addition of heavy metals to the forest soil through leaching can cause environmental damage. Mining activity in forests has always caused environmental damage (Siqueira-Gay et al. 2020). Based on the results of this study and other studies (Modarres and Nosoudy 2015), it can be concluded that the use of coal waste with lime may cause reactions, which not only increases the mechanical strength of the soil and gives rise to larger crystals but can also reduce pollution by reducing heavy metal concentrations. According to the results of chemical analysis, the most important reason for the increase in $\mathrm{pH}$ is the addition of lime and alkalinity of the soil. Over-alkalization of the soil can affect the vegetation cover. Increased $\mathrm{pH}$ can cause the elimination of some plant species and increase the invasive species consistent with calcareous soil conditions. Changes in the concentration of elements such as N, P, K and C can also influence the growth of plant species along the roads. So, it is better to use less of these materials. Of course, the optimum level should be considered. Due to the fact that stabilizers are used in the road layers, the leaching process can transfer a percentage of them to the road side and the concentration of the mentioned elements is not directly related to the soil along the road. There are many coal washing plants around the forests whose waste affects the environment. Implementation of waste material reduces the land occupation. In addition, it reduces the contaminating impacts of such materials on the surrounding area especially the surface and underground water resources. Therefore, it can be helpful to use wastes materials in the construction projects. According to 
the standards of forest roads construction of Iran, about $50 \%$ of forest roads are usually access roads. The materials for the base and subbase layers are selected from river bed (extraction of sand, gravel from river bed) and mountain (broken stone with a hammer). River bed sand and gravel are used more than mountain materials due to their availability and low costs. The use of river materials in the pavement layers reduces the bearing capacity and strength of surface materials due to the presence of clay and silt. In this study, it was found that the addition of coal waste to the soil causes changes in the mechanical and chemical properties of the soil. Due to the large amounts of silica in the coal waste, the Pozzolanic activity can increase the size of soil aggregates. Asphalt is not usually used for the pavement layer of forest roads in Iran. Therefore, soil stabilization can have a positive effect on the strength of pavement and reduction of runoff and sediment by reducing fine materials. By comparing the results of this study with the international standards (Recommendations of the Environmental Protection Agency of America), it was determined that the coal waste can be one of the suggested options for the road stabilization. Further environmental studies are needed to use these compounds in the nature. First, these compounds should be used as pilots in the road pavement and after confirming the results, these materials could be used in the forest road construction and maintenance projects.

\section{Conclusions}

According to the laboratory results, the following conclusions are obtained:

$\Rightarrow$ according to the Aterberg limit tests, coal waste affects the plastic behavior. The combinations of $\mathrm{S}+4 \mathrm{~L}+6 \mathrm{CW}$ and $\mathrm{S}+6 \mathrm{~L}+6 \mathrm{CW}$ showed the best results in the reduction of liquid limits

$\Rightarrow$ the increase of coal wastes for the samples with 4 and $6 \%$ lime decreased the maximum dry density and increased the optimum moisture content

$\Rightarrow$ the use of coal waste and lime increased the strength properties of stabilized soil. The lime activated coal waste resulted in higher CBR and unconfined compressive strength than the corresponding clay soil containing the coal waste solely

$\Rightarrow$ according to the XRD pattern, the addition of $\mathrm{CW}$ and lime increased the quartz intensity and size of crystals in soil minerals

$\Rightarrow$ the use of coal waste and lime not only improves the soil technical properties but also reduces the concentration of heavy metals and its harmful effects to environment. After the addition of $\mathrm{CW}$ and lime to the soil, all of the metal concentra- tions leached from samples satisfied the required criteria. So, the stabilization method can be one of the best techniques for in situ remediation of some pollutant materials

$\Rightarrow$ in general, the addition of lime and CW significantly increased the concentration of $\mathrm{N}, \mathrm{P}, \mathrm{K}$. Also, over-alkalization of the soil can affect the vegetation cover. This changes can increase the invasive species consistent with calcareous soil conditions and also influence the growth of plant species along the roads

$\Rightarrow$ this study suggests the lowest amount (4\%) of lime for soil stabilization. According to the results, the combination of S+4L+9CW could be used as the optimum consumption of materials for the stabilization of access roads.

\section{References}

Ahmed, A., 2015: Compressive strength and microstructure of soft clay soil stabilized with recycled basanite Appl. Clay Sci. 104: 27-35. https://doi.org/10.1016/j.clay.2014.11.031

ASTM D854, 2014: Standard Test Methods for Specific Gravity of Soil Solids by Water Pycnometer. Annual Book of ASTM Standards, USA.

ASTM D4318, 2003: Test Method for Liquid Limit, Plastic Limit and Plasticity Index of Soils. Annual Book of ASTM Standards, USA.

ASTM, 2002: Test Methods for Laboratory Compaction Characteristics of Soil Using Standard Effort (D0698-07E01). Annual Books of ASTM Standard. Section 4 Vol. 0408 USA.

ASTM, 2002: Test Methods for Liquid Limit, Plastic Limit, and Plasticity Index of Soils (D4318-05). Annual Books of ASTM Standard, Section 4 Vol. 0408 USA.

ASTM, 2002: Test Methods for CBR (California Bearing Ratio) of Laboratory Compacted Soils (D1883-07). Annual Books of ASTM Standard, Section 4 Vol. 0408 USA.

Chobbasti, A.J., Ghodrati, H., Vahdatirad, M.J., Firouzian, S., Barari, A., Torabi, M., Bagherian, A., 2010: Influence of using rice husk ash in soil stabilization method with lime. Frontiers of Earth Science in China 4(4): 471-480. https://doi.org/10.1007/ s11707-010-0138-x

Consoli, N.C., Lopes, L.S., Heineck, K.S., 2009: Key parameters for the strength control of lime stabilized soils. ASCE J. Mater. Civ. Eng. 21(5): 210-216. https://doi.org/10.1061/(ASCE)08991561(2009)21:5(210)

Fauzi, A., Nazmi, W.M., Abdul-Rahman, W., Jauhari, Z., 2013: Utilization waste material as stabilizer on Kuantan clayey soil stabilization. Procedia Eng. 53: 42-47. https://doi.org/10.1016/j. proeng.2013.02.007

García, R.M., Fríasa, M.I., Sanchez de Rojas, A., Juan Valdés, C., 2012: Effect of activated coal mining wastes on the properties of blended cement. Cement and Concrete Composite 34(5): 678683. https://doi.org/10.1016/j.cemconcomp.2012.02.006

Harichane, K., Ghrici, M., Kenai, S., 2011: Effect of curing time on shear strength of cohesive soils stabilized with combination of lime and natural pozzolana. International Journal of Civil Engineering 9(2): 90-96. 
Hruza, P., Blahuta, J., Pelikan, P., Olisarova, L., Nedorost, J., Mikita, T., Patocka, Z., 2020. Recycled asphalt as an alternative to natural aggregates for forest road reinforcement. Croatian journal of forest engineering 41(1): 149-161. https://doi. org/10.5552/crojfe.2020.571

Kamei, T., Ahmed, A., Ugai, K., 2013. Durability of soft clay stabilized with recycled bassanite and furnace cement mixtures. Soils and Foundations 53(1): 155-165. https://doi.org/10.1016/j. sandf.2012.12.011

Khemissa, M., Mahamedi, A., 2014: Cement and lime mixture stabilization of an expansive over consolidated clay. Appl. Clay Sci. 95: 104-110. https://doi.org/10.1016/j.clay.2014.03.017

Kumpiene, J., Lagerkvist, A., Maurice, C., 2007: Stabilization of $\mathrm{Pb}$ and $\mathrm{Cu}$ contaminated soil using coal fly ash and peat. Environ. Pollut. 145(1): 365-373. https://doi.org/10.1016/j.envpol.2006.01.037

Lee, S.H., Kim, E.Y., Park, H., Yun, J., Kim, J.G., 2011: In situ stabilization of arsenic and metal-contaminated agricultural soil using industrial by-products. Geoderma 161(1-2): 1-7. https:// doi.org/10.1016/j.geoderma.2010.11.008

Li, L., Lei, Y., Pan, D., 2015: Economic and environmental evaluation of coal production in China and policy implications. Nat. Hazards 77: 1125-1141. https://doi.org/10.1007/s11069-015-16509

Modarres, A., Nosoudy, Y.M., 2015: Clay stabilization using coal waste and lime- technical and environmental impacts. Appl. Clay Sci. 116-117: 281-288. https://doi.org/10.1016/j. clay.2015.03.026
Modarres, A., Hesami, S., Soltaninejad, M., Madani, H., 2018: Application of coal waste in sustainable roller compacted concrete pavement-environmental and technical assessment, Int. J. Pavement Eng 19: 748-761. https://doi.org/10.1080/10298436.20 16.1205747

Ramezanianpour, A.A., Khani, M.M., Ahmadibeni, G.H., 2009: The Effect of Rice Husk Ash on Mechanical Properties and Durability of Sustainable Concretes. International Journal of Civil Engineering 7(2): 83-91.

Seco, A., Ramirez, F., Miqueleiz, L., Garcia, B., 2011: Stabilization of expansive soils for use in construction. Appl. Clay Sci. 51(3): 348-352. https://doi.org/10.1016/j.clay.2010.12.027

Sezer, A., Inan, G., Yilmaz, R., Ramyar, K., 2006: Utilization of a very high lime fly ash for improvement of Izmir clay. Build. Environ. 41(2): 150-155. https://doi.org/10.1016/j.buildenv.2004.12.009

Siqueira-Gay, J., Sonter, J.L., Sánchez L.E., 2020: Exploring potential impacts of mining on forest loss and fragmentation within a biodiverse region of Brazil's northeastern Amazon. Resources Policy 67: 101662. https://doi.org/10.1016/j. resourpol.2020.101662

Taslimi Paein Afrakoti, M., Janalizadeh Choobbasti, A., Ghadakpour, M., Soleimani Kutanaei, S., 2020: Investigation of the effect of the coal wastes on the mechanical properties of the cement-treated sandy soil. Construction and Building Materials 239: 117-128. https://doi.org/10.1016/j.conbuildmat.2019.117848 USEPA 1311, 1992: Toxicity Characteristics Leaching Procedure. United States Environment Protection Agency, USA. of the Creative Commons Attribution (CC BY) license (http://creativecommons.org/licenses/by/4.0/).

Received: March 08, 2020

Accepted: March 02, 2021
Authors' addresses:

Sara Mansouri, MSc

e-mail: sara.mansouri19@gmail.com

Assist. prof. Mehran Nasiri, PhD*

e-mail: me.nasiri@sanru.ac.ir

Sari University of agricultural sciences

and natural resources

Faculty of natural resources

Department of Forest engineering

Mazandaran, Sari, Badeleh,

P.O. Box \#737

IRAN

Assoc. prof. Amir Modarres, $\mathrm{PhD}$

e-mail: a.modarres@nit.ac.ir

Babol Noshirvani University of Technology

Department of civil engineering

Mazandaran, Babol, Shariati

Av., P.O. Box: 484

Postal Code: 47148 - 71167

IRAN

* Corresponding author 